Review

\title{
Should EMT of Cancer Cells Be Understood as Epithelial-Myeloid Transition?
}

\author{
Henning M. Schramm $\bowtie$ \\ Institute Hiscia, Society for Cancer Research, CH-4144 Arlesheim/Switzerland. \\ $\triangle$ Corresponding author: e-mail: h.schramm@vfk.ch \\ () Ivyspring International Publisher. This is an open-access article distributed under the terms of the Creative Commons License (http://creativecommons.org/ \\ licenses/by-nc-nd/3.0/). Reproduction is permitted for personal, noncommercial use, provided that the article is in whole, unmodified, and properly cited.
}

Received: 2013.11.28; Accepted: 2014.01.02; Published: 2014.01.15

\begin{abstract}
Cancer cells express epithelial markers, and when progressing in malignancy they may express markers of the mesenchymal cell type. Therefore an epithelial-mesenchymal transition of the cancer cells is assumed. However the mesenchymal markers can equally well be interpreted as myeloid markers since they are common in both types of cell lineages. Moreover, cancer cells express multiple specific markers of the myeloid lineages thus giving rise to the hypothesis that the transition of cancer cells may be from epithelial to myeloid cells and not to mesenchymal cells. This interpretation would better explain why cancer cells, often already in their primary cancer site, frequently show properties common to those of macrophages, platelets and pre-/osteoclasts.
\end{abstract}

Key words: Epithelial-mesenchymal transition, epithelial-myeloid transition, osteomimetic properties of cancer cells; macrophage and platelet traits of cancer cells, common clusters of differentiation between cancer cells and cells of the myeloid lineage

\section{Introduction}

The epithelial-mesenchymal transition (EMT) of cancer cells is assumed to be a process that causes a functional and phenotypical transition of polarised epithelial cells into the migratory extracellular matrix producing mesenchymal cells. In order to acquire a mesenchymal migratory phenotype (motility and invasiveness), cancer cells must shed many of their epithelial characteristics, detach from the epithelial sheet and undergo a drastic alteration. It appears therefore that EMT is a key developmental programme often activated during cancer invasion and metastasis [1, 2].

This hypothesis is based on the fact that key mesenchymal markers, such as vimentin, fibronectin, N-Cadherin, alphavbeta3-integrins and FSP-1, can be detected in a subset of cancer cells. The EMT seems to pathologically recapitulate the normal epithelial-mesenchymal transition occurring during mammalian development, and is thought to be to some extent comparable to the EMT during physiological wound healing [3]. However, there is some incongruity in this hypothesis, as it cannot explain why cancer cells with mesenchymal markers show many specifically phenotypical and functional traits of monocytes, macrophages, platelets and pre-/osteoclasts, i.e. traits of the myeloid lineage cells [4-11].

The key mesenchymal markers are not specific to mesenchymal cells, but can also be found in cells of the hematopoietic lineage, and especially in the myeloid lineage. [12] We therefore raise the question whether the transition of cancer cells can be interpreted as an epithelial-myeloid transition. This would explain the peculiar properties of cancer not in accord with their assumed mesenchymal character, which have therefore so far been interpreted as a kind of mimicry of properties of the myeloid lineage cells.

\section{Osteomimetic properties of cancer cells}

Multiple publications describe the osteomimetic properties of cancer cells and relate this to their bone metastasizing tendency [13-18]. Most known human 
carcinomas show an increased expression of bone-specific proteins, i.e. osteopontin, osteocalcin and sialoprotein [16]. The expression of bone-specific proteins by primary tumour cells is not restricted to cancer cells metastasizing to bone, but is a general feature of the malignant phenotype. Moreover cancer cells in the primary tumour site express various enzymes commonly expressed by osteoclasts as well, such as MMP-9, TRAP, Cathepsin-K, carbonic anhydrase and the vacuolic H+-ATPase [19-21]. These features do not comply with the assumed epithelial character or mixed epithelial-mesenchymal character of cancer cells in the primary or metastatic site. Cancer cells are usually thought to originate in the epithelium from epithelial cells, and the question arises how cancer cells of epithelial origin can adopt osteomimetic properties.

\section{More preosteoclastic traits of cancer cells}

The functional properties of cancer cells also reflect specifically preosteoclastic behaviour. These are: matrix-resolving properties, hormone and neuronal dependence, coupling with mesenchymal cells, migrating and transmigrating properties, neurogenetic properties, trafficking to the bone, immune competence, sensitivity to antirheumatics, bisphosphonates, polyphenols and steroids [7]. Most of these characteristics do not comply with the behaviour of mesenchymal cells. Immune competence is a decisive trait of cells of the myeloid lineage and is uncharacteristic of matured mesenchymal cells. The immune competence of the cancer cells is however one decisive hallmark of cancer cells. It contributes to their malignancy and therapy resistance as it can deviate all immune strategies, avoiding repulsion or elimination of the tumour. Another characteristic trait of pre-/osteoclasts is their coupling with mesenchymal cells, i.e. with osteoblasts. The development of pre-osteoclasts depends on their interaction with osteoblasts. It has been well demonstrated that cancer cells need co-conspirators for their development such as tumour-associated fibroblasts, i.e. cells of the mesenchymal lineage. Cancer cells depend for their progression on coupling with mesenchymal cells i.e. the tumour-associated fibroblasts, in the same way that pre-/osteoclasts depend on osteoblasts for their differentiation.

When preosteoclasts fuse into an osteoclast they intracellularly overexpress certain signalling pathways which are likewise overexpressed in cancer cells during their proliferation [22].

\section{Common clusters of differentiation be- tween cancer cells and cells of the mye- loid lineage}

Comparing the surface markers of cancer cells with those of osteoclasts and their myeloid lineage progenitors, we detect multiple correspondences. The following clusters of differentiation commonly expressed by myeloid cells including pre- and osteoclast cells are surface markers of various cancer cells as well: CD9 - CD11b, CD13 - CD15, CD18, CD20, CD24, CD26, CD30, CD31, CD36, CD38, CD40, CD 41, CD43 - CD 47, CD49, CD51, CD53 - CD56, CD58, CD59, CD61, CD63, CD68, CD70, CD71, CD73, CD80/86, CD 81, CD82, CD86, CD87, CD90, CD95, CD97, CD 98, CD 105, CD106, CD112, CD115, CD117, CD124, CD133, CD137, CD146, CD147 CD151, CD155, CD163, CD164, CD166, CD171, CD184, CD200, CD227, CD274 and CD326 (for references see table 1)

We can conclude from the clusters of differentiation that various stages of myeloid lineage, from stem cells to mature cells, can be detected in cancer cell lines and in cancer tumours. As far as we are aware, many of these clusters of differentiation have not so far been detected on mesenchymal cells as CD10, CD11, CD14, CD18, CD20, CD45 and others see table 1 .

Table I: Common clusters of differentiation among epithelial, cancer, mesenchymal and myeloid cells. In the lines of epithelial and mesenchymal cells, account is taken of the indications published in: Charles Janeway et al.: The Immune System in Health and Disease, Taylor and Francis Books Inc. New York 200I (5 ${ }^{\text {th }}$ edition).

\begin{tabular}{|c|c|c|c|c|c|}
\hline Clusters of differentiation & $\begin{array}{l}\text { Cells of myeloid } \\
\text { origin }\end{array}$ & $\begin{array}{l}\text { Cancer } \\
\text { cells }\end{array}$ & Epithelial cells & $\begin{array}{l}\text { Mesenchymal } \\
\text { cells }\end{array}$ & References \\
\hline CD9 & + & + & + & + & {$[36-40]$} \\
\hline CD10 & + & + & + & - & {$[41-43]$} \\
\hline CD11a, b (CD11b/ CD18= Mac-1; CD11a/ CD18=LFA-1) & + & + & - & - & {$[44,40]$} \\
\hline CD13 & + & + & - & + & {$[40,45]$} \\
\hline CD14 & + & + & - & - & {$[40,44,46]$} \\
\hline CD15 (Lewis X) & + & + & - & + & {$[47,48]$} \\
\hline CD18 & + & + & - & - & {$[40,49]$} \\
\hline CD20 & + & + & - & - & {$[50,51]$} \\
\hline CD24 & + & + & - & + & {$[52-54]$} \\
\hline
\end{tabular}




\begin{tabular}{|c|c|c|c|c|c|}
\hline CD26 (Mannose receptor) & + & + & - & - & {$[6,43]$} \\
\hline CD30 & + & + & - & - & {$[55,56]$} \\
\hline CD31 (PECAM-1) & + & + & - & + & [57] \\
\hline CD36 (Fatty acid transporter, TSP receptor) & + & + & + & + & {$[58-60]$} \\
\hline CD38 & & + & - & - & {$[50,61,62]$} \\
\hline $\mathrm{CD} 40$ & + & + & + & - & {$[40,63,64]$} \\
\hline CD41 & + & + & - & - & {$[65-67]$} \\
\hline CD43 & + & + & - & - & [68] \\
\hline CD44 & + & + & + & + & [69] \\
\hline CD45 & + & + & - & - & {$[40,48,55]$} \\
\hline CD46 (membrane cofactor protein $\mathrm{MCP}$ ) & + & + & - & - & {$[70,71]$} \\
\hline CD47 (Thrombospondin-1 receptor) & + & + & + & + & {$[72,73]$} \\
\hline $\mathrm{CD} 49$ & + & + & + & + & {$[43,74]$} \\
\hline $\begin{array}{l}\text { CD51 Alpha V; CD51/CD61: Vitronectin Receptor (integrin al- } \\
\text { phaVbeta3) }\end{array}$ & + & + & + & + & [75] \\
\hline CD53 & + & + & + & - & {$[40,76]$} \\
\hline CD54 (Icam-1) & + & + & + & + & $\begin{array}{l}{[40,43,48,} \\
72]\end{array}$ \\
\hline CD55 (DAF) & + & + & + & + & {$[70,71]$} \\
\hline CD56 & + & + & - & - & {$[70,77,78]$} \\
\hline CD58 & + & + & + & + & {$[40,72]$} \\
\hline CD59 & + & + & + & + & {$[71,79]$} \\
\hline CD61 (beta3 integrin) & + & + & + & - & {$[80,81]$} \\
\hline CD63 & + & + & + & - & {$[40,70,82]$} \\
\hline CD68 (KP1) & + & + & - & + & $\begin{array}{l}{[40,48,83,} \\
84]\end{array}$ \\
\hline CD70 & + & + & - & - & {$[85,86]$} \\
\hline CD71 (Transferrin receptor) & + & + & + & + & {$[48,87]$} \\
\hline CD73 & + & + & + & + & {$[87-89]$} \\
\hline $\begin{array}{l}\text { CD80/86 } \\
\text { (B7) }\end{array}$ & + & + & - & - & {$[40,90,91]$} \\
\hline CD81 & + & + & - & - & {$[87,92]$} \\
\hline CD82 & + & + & + & & {$[92,39]$} \\
\hline CD86 & + & + & - & - & {$[40,91,93]$} \\
\hline CD87 (Urokinase plasminogen activator receptors $=\mathrm{uPAR}$ ) & + & + & + & + & {$[40,94,95]$} \\
\hline CD90 & + & + & - & + & {$[46,96,97]$} \\
\hline CD95 (FasR) & & + & - & - & {$[50,98]$} \\
\hline CD97 & + & + & - & - & {$[87,99]$} \\
\hline CD98 & + & + & - & - & {$[100,101]$} \\
\hline CD105 & + & + & - & + & {$[43,102,103]$} \\
\hline CD106 (VICAM-1) & + & + & - & + & {$[40,104]$} \\
\hline CD112 (Nectin-2) & + & + & + & + & [105 - 107] \\
\hline CD115 (c-FMS) & + & + & + & & {$[108,109]$} \\
\hline CD117 (c-Kit) & + & + & - & + & {$[110,111]$} \\
\hline CD124 (Interleukin-4 Receptor) & + & + & - & - & {$[112,113]$} \\
\hline CD133 & + & + & + & - & [114 - 116] \\
\hline CD137 & + & + & + & - & {$[117,118]$} \\
\hline CD146 & + & + & - & + & {$[119-122]$} \\
\hline $\begin{array}{l}\text { CD147 }(\text { Basigin, Emmprin = Extra-cellular matrix metal- } \\
\text { lo-proteinase inducer) }\end{array}$ & + & + & - & + & {$[40,123]$} \\
\hline CD151 & + & + & + & + & {$[87,92]$} \\
\hline CD155 & + & + & - & - & {$[40,124]$} \\
\hline CD163 & + & + & - & - & {$[8,40,125]$} \\
\hline CD164 & + & + & + & - & {$[43,126,127]$} \\
\hline CD166 (ALCAM) & + & + & + & + & {$[128,129]$} \\
\hline CD171 (L1CAM) & + & + & + & - & {$[40,130]$} \\
\hline CD184 (CXCR4) & + & + & - & - & {$[43,131]$,} \\
\hline CD200 & + & + & - & - & {$[40,132]$} \\
\hline CD227 (Mucin1) & + & + & + & - & {$[25,43,133]$} \\
\hline CD274 (CPOD-L1, B7-H1, Programmed death ligand 1) & + & + & - & - & {$[134,135]$} \\
\hline CD326 (Epcam) & + & + & + & - & [24 - 136] \\
\hline
\end{tabular}




\section{Other common surface markers}

Other than the above cited clusters of differentiation, there are a multiplicity of surface markers expressed by both cancer and myeloid lineage cells, of which we will name only the following: TLRs, RANK, ADAM, DAP12, OSCAR, MAC387, NK1 receptor, BMP receptor, Protease activated receptor-1, TRAF-6 and calcitonin receptor. The calcitonin receptor and TRAP are specific osteoclast markers [23]. These cell markers are neither expressed by epithelial cells nor by mesenchymal cells. This demonstrates that cancer cells, even in their primary site, are more related to the various stages of myeloid cells, i.e. passing from stem cells to progenitor cells of monocytes, dendritic cells, macrophages through to osteoclasts. Thus we can question the mesenchymal character of cancer cells undergoing the hypothesized EMT.

\section{Epithelial markers of cancer cells}

Cancer cells are thought to be of epithelial origin due to their epithelial markers. But certain cells of the myeloid lineage, the Langerhans cells, usually adopt some epithelial markers as well. Langerhans cells show a high degree of epithelial surface markers CD326 (EpCAM) [24], CD227 (Mucin1) [25], and E-Cadherin [26] in the epidermis, thereby connecting them with keratinocytes. Whether they may also adopt a local cytokeratin scaffold has so far not been described to our knowledge. In connection with these epithelial markers of the myeloid lineage cells, it is noteworthy that haematopoietic lineage-committed bone marrow cells and not cloned cultures of mesenchymal cells contribute to the regeneration of renal tubular epithelium after $\mathrm{HgCl} 2$-induced acute tubular injury [27]. It seems that the hematopoietic stem cells transdifferentiate into renal tubular epithelial cells or at least become incorporated appropriately into renal tubular epithelium after acute renal tubular damage. The transdifferentiation of haematological stem cell into epithelial cells may be due to cell fusion [27, 28].

\section{Are epithelial cells required for carcino- genesis?}

We not only question the epithelial-mesenchymal transition, but also the purely epithelial origin of cancer cells. MTA transgenic mice are further evidence that epithelial cells alone cannot induce carcinogenesis in the skin. Cells of the myeloid lineage, like Langerhans cells in the epidermis, are required for carcinogenesis. Researchers expected MTA transgenic mice to be very prone to skin carcinogenesis due to the lack of Langerhans cells in their epidermis. The contrary was the case. The animals are resistant to squamous cell carcinoma induction in the skin $[29,30]$. This fact can be explained by the hypothesis that cells of myeloid origin, and not epithelial cells alone, are a prerequisite for carcinogenesis.

The MTA transgenic mice are deficient in MHC-II positive cells in the epidermis and therefore Langerhans cells or any other myeloid cells are completely absent in the epidermis [31]. The fraction of MHC-II cells in the epidermis represent dendritic/Langerhans cells which still retain sufficient plasticity and consequently the potential to transdifferentiate into pre-/osteoclasts. Various in-vitro and in-vivo studies demonstrate this transdifferentiation of dendritic cells, e.g. in a rheumatoid arthritis microenvironment [32]. We can assume that this plasticity applies to the Langerhans cell as a subset of dendritic cells too.

\section{Origin of cancer cells, and progenitor cells}

The myeloid characteristics of cancer cells may lead us to ask whether these cells are really of epithelial origin or rather, at least in part, of myeloid origin. In the steady state of the epidermis, the Langerhans cells multiply in the skin and remain there for many years without being replaced by circulating monocytes. In the case of oxidative stress induced for example by UV irradiation or chemically by DMBA-TPA application, the resident Langerhans cells are depleted and replaced by circulating bone marrow-derived monocytes, which differentiate into Langerhans cells in the epidermis. If the oxidative stress continues over a longer period, a microenvironment arises in the epidermis that is characterized by the activity of M-CSF, RANKL and hypoxia signalling [29]. This network may direct the MHC-II positive cells to transdifferentiate in the direction of pre-/osteoclasts, since the same environment governs the fusing of certain monocytes at the bone site during their differentiation into osteoclasts. Other still unknown factors may play a role in this process. The preosteoclasts derived from dendritic cells, surprisingly, are more prone to fuse than preosteoclasts directly derived from the bone marrow monocyte [32]. We hypothesise that under the described circumstances these cells fuse with keratinocyte or melanocyte progenitors expressing the fusion marker CD98 in the basal cell layer. As this fusion occurs via inadequate partners, it may result in aneuploidy and the merged characteristics of myeloid cells with keratinocytes or melanocytes, which are specific features of cancer cells. These cells have thus activated all the signalling pathways normally activated when monocytes/preosteoclasts fuse into osteoclasts at bone sites [22]. 


\section{Where carcinogenesis is absent}

We have described the MTA mice where carcinogenesis cannot be induced due to the lack of MHC II positive cells in the epidermis. A comparable situation has been described for the inner ear, which likewise seems resistant to carcinogenesis [33]. So far no primary cancer has been detected and described in the inner ear even in the case of chronic inflammation. This may be due to inhibition of differentiation of monocytes and Langerhans cells into osteoclasts, in this case caused by extremely high levels of osteoprotegerin and reduced expression of M-CSF and IGF-1.

A third example is the naked mole rat which does not develop cancer. There are various hypotheses for the lack of carcinogenesis in these animals, but none seems to be conclusive so far $[34,35]$.

\section{Conclusions}

On the basis of phenotypical features, functional characteristics and specific intracellular signalling activities, we hypothesise that cancer cells at least partly originate from the myeloid lineage. Cancer cells can be seen in different stages of the myeloid lineage passing - with the additional feature of malignancy - from bone marrow stem cells via monocytes through to pre- and osteoclasts. We can conclude that the osteomimetic properties of cancer cells are inherent properties of these cells and consequently cannot be interpreted as hoaxed and opportunistic features of mesenchymal cancer cells arising only for metastasis purposes in the bone. It is uncertain as yet whether the fusogenic properties of macrophages and preosteoclasts or their plasticity allow them to adopt local cytokeratin characteristics, and how these aspects may be connected with their malignancy. This is an issue for further research.

Based on these findings, the hypothesis of an epithelial-mesenchymal transition of cancers in their progression to metastasis must be severely questioned. The markers interpreted as mesenchymal markers of cancers cell can be judged as myeloid markers as well because they are common to both types of cells. Based on the phenotypical features and their functional properties in cancer, we propose another transition hypothesis. In a transition such as the phenotypical change in cancer cells apparent during their malignancy progression, an epithelial-myeloid transition would better explain the various features of the cancer's malignancy.

Table 2: Common highly expressed markers shared by cancer and myeloid cells with high specificity for these cells.

\begin{tabular}{|c|c|c|c|c|}
\hline Markers & $\begin{array}{l}\text { Monocyte and } \\
\text { pre-/osteoclast markers }\end{array}$ & Cancer cells & Expression in other cells & References \\
\hline TRAP & $\begin{array}{l}\text { Osteoclasts, activated } \\
\text { macrophages }\end{array}$ & Breast, ovary, cervix, melanoma & Neurons & {$[21,137,138]$} \\
\hline RANK & Preosteoclast & $\begin{array}{l}\text { Breast, melanoma, prostate, colo- } \\
\text { rectal, kidney, lung, head and } \\
\text { neck, liver }\end{array}$ & $\begin{array}{l}\text { Epithelial cells in mammary gland } \\
\text { during pregnancy }\end{array}$ & {$[19,139]$} \\
\hline Cathepsin K & Osteoclasts, macrophages & Breast, lung, prostate & Inflammatory dermal fibroblasts & {$[19,140]$} \\
\hline MMP-9, MMP-2 & Osteoclasts, macrophages & $\begin{array}{l}\text { Prostate, breast, glioma, head and } \\
\text { neck, colorectum, bladder, lung }\end{array}$ & $\begin{array}{l}\text { Connective tissue and inflammatory } \\
\text { fibroblasts }\end{array}$ & [19] \\
\hline Calcitonin receptor & Osteoclasts & Glioblastoma, prostate, breast & - & [19] \\
\hline DAP12 & $\begin{array}{l}\text { Pre-/osteoclasts, dendritic } \\
\text { cells }\end{array}$ & breast & - & {$[8,141,142]$} \\
\hline $\begin{array}{l}\text { BMP receptor } \\
\text { (Bone morphogenetic } \\
\text { protein receptor) }\end{array}$ & Preosteoclasts & Breast, prostate & Neurons & {$[19,143]$} \\
\hline $\begin{array}{l}\text { Carbonic anhydrase } 2 \\
\text { and } 12\end{array}$ & Osteoclasts & $\begin{array}{l}\text { Kidney, lung, head and neck, } \\
\text { glioma, breast }\end{array}$ & Stomach and peritoneal lining, $\mathrm{CAF}$ & {$[20,144]$} \\
\hline PTHrP, PTH1R & Preosteoclasts, osteoclasts & $\begin{array}{l}\text { Breast, lung, head and neck, } \\
\text { prostate, kidney, colorectum }\end{array}$ & $\begin{array}{l}\text { Osteoblasts, mammary gland during } \\
\text { lactation, kidney epithelial cells }\end{array}$ & [145 - 148] \\
\hline TLR4 & Osteoclasts, Macrophages & $\begin{array}{l}\text { Colon, lung, head and neck, SCC } \\
\text { of oesophagus, melanoma }\end{array}$ & Epithelial cells & [149] \\
\hline ADAM12 / HER2 & Pre-/osteoclasts & Breast, head and neck & Tumor stroma & {$[150$ - 152] } \\
\hline Notch-1 receptor & $\begin{array}{l}\text { Preosteoclasts, monocytes, } \\
\text { dendritic cells }\end{array}$ & $\begin{array}{l}\text { Breast, melanoma, pancreas, my- } \\
\text { eloma, head and neck, colorec- } \\
\text { tum, lung, liver }\end{array}$ & $\begin{array}{l}\text { Angiogenesis; } \\
\text { spatio-temporal regulation }\end{array}$ & {$[153,154]$} \\
\hline
\end{tabular}




\section{Competing Interests}

The authors have declared that no competing interest exists.

\section{References}

1. van der Pluijm G: Epithelial plasticity, cancer stem cells and bone metastasis formation. Bone 2011:48(1):37-43.

2. Creighton CJ, Gibbons DL, Kurie JM: The role of epithelial-mesenchymal transition programming in invasion and metastasis: a clinical perspective. Cancer Manag Res 2013;5:187-95.

3. Weber CE, Li NY, Wai PY, Kuo PC: Epithelial-mesenchymal transition, TGF-beta, and osteopontin in wound healing and tissue remodeling after injury. J Burn Care Res 2012;33(3):311-8.

4. Huysentruyt LC, Seyfried TN: Perspectives on the mesenchymal origin of metastatic cancer. Cancer Metastasis Rev 2010;29(4):695-707.

5. Huysentruyt LC, Mukherjee P, Banerjee D, Shelton LM, Seyfried TN: Metastatic cancer cells with macrophage properties: evidence from a new murine tumor model. Int J Cancer 2008;123(1):73-84.

6. Ruff MR, Pert CB: Small cell carcinoma of the lung: macrophage-specific antigens suggest hemopoietic stem cell origin. Science 1984;225(4666):1034-6.

7. Schramm HM: Extraterritorial osteoclast traits of primary cancer cells. Journal of Solid tumors 2011:1(2):65-79.

8. Shabo I, Svanvik J: Expression of macrophage antigens by tumor cells. Adv Exp Med Biol 2011;714:141-50.

9. Timar J, Tovari J, Raso E, Meszaros L, Bereczky B, Lapis K: Platelet-mimicry of cancer cells: epiphenomenon with clinical significance. Oncology 2005;69(3):185-201.

10. Pawelek JM: Tumour-cell fusion as a source of myeloid traits in cancer. Lancet Oncol 2005;6(12):988-93.

11. Pawelek J, Chakraborty A, Lazova R, Yilmaz Y, Cooper D, Brash D, Handerson T: Co-opting macrophage traits in cancer progression: a consequence of tumor cell fusion? Contrib Microbiol 2006;13:138-55.

12. Pilz GA, Braun J, Ulrich C, Felka T, Warstat K, Ruh M, Schewe B, Abele H, Larbi A, Aicher WK: Human mesenchymal stromal cells express CD14 cross-reactive epitopes. Cytometry A 2011;79(8):635-45.

13. Koeneman KS, Yeung F, Chung LW: Osteomimetic properties of prostate cancer cells: a hypothesis supporting the predilection of prostate cancer metastasis and growth in the bone environment. Prostate 1999;39(4):246-61.

14. Bellahcene A, Merville MP, Castronovo V: Expression of bone sialoprotein, a bone matrix protein, in human breast cancer. Cancer Res 1994;54(11):2823-6.

15. Gillespie MT, Thomas RJ, Pu ZY, Zhou H, Martin TJ, Findlay DM: Calcitonin receptors, bone sialoprotein and osteopontin are expressed in primary breast cancers. Int J Cancer 1997;73(6):812-5

16. Bellahcene A, Castronovo V, Ogbureke KU, Fisher LW, Fedarko NS: Small integrin-binding ligand $\mathrm{N}$-linked glycoproteins (SIBLINGs): multifunctional proteins in cancer. Nat Rev Cancer 2008;8(3):212-26.

17. Huang WC, Xie Z, Konaka H, Sodek J, Zhau HE, Chung LW: Human osteocalcin and bone sialoprotein mediating osteomimicry of prostate cancer cells: role of cAMP-dependent protein kinase A signaling pathway. Cancer Res 2005;65(6):2303-13.

18. Chaplet M, De Leval L, Waltregny D, Detry C, Fornaciari G, Bevilacqua G, Fisher $\mathrm{LW}$, Castronovo V, Bellahcene A: Dentin matrix protein 1 is expressed in human lung cancer. J Bone Miner Res 2003;18(8):1506-12.

19. Yamashita M, Otsuka $F$, Mukai $T$, Yamanaka $R$, Otani $H$, Matsumoto $Y$, Nakamura $E$ Takano M, Sada KE, Makino H: Simvastatin inhibits osteoclast differentiation induced by bone morphogenetic protein-2 and RANKL through regulating MAPK, AKT and Src signaling. Regul Pept 2010;162(1-3):99-108.

20. Neri D, Supuran CT: Interfering with $\mathrm{pH}$ regulation in tumours as a therapeutic strategy. Nat Rev Drug Discov 2011:10(10):767-77.

21. Adams LM, Warburton MJ, Hayman AR: Human breast cancer cell lines and tissues express tartrate-resistant acid phosphatase (TRAP). Cell Biol Int 2007;31(2):191-5.

22. Schramm HM: The cross-over of anticancer agents wit osteoclast activities. Current Cancer Therapy Reviews 2011;7(4):290-302.

23. Fujikawa Y, Sabokbar A, Neale S, Athanasou NA: Human osteoclast formation and bone resorption by monocytes and synovial macrophages in rheumatoid arthritis. Ann Rheum Dis 1996;55(11):816-22.

24. Gaiser MR, Lammermann T, Feng X, Igyarto BZ, Kaplan DH, Tessarollo L, Germain RN, Udey MC: Cancer-associated epithelial cell adhesion molecule (EpCAM; CD326) enables epidermal Langerhans cell motility and migration in vivo. Proc Natl Acad Sci U S A 2012;109(15):E889-97.

25. Wykes M, MacDonald KP, Tran M, Quin RJ, Xing PX, Gendler SJ, Hart DN, McGuckin MA: MUC1 epithelial mucin (CD227) is expressed by activated dendritic cells. J Leukoc Biol 2002;72(4):692-701.

26. Tang A, Amagai M, Granger LG, Stanley JR, Udey MC: Adhesion of epidermal Langerhans cells to keratinocytes mediated by E-cadherin. Nature 1993;361(6407):82-5.

27. Fang TC, Otto WR, Rao J, Jeffery R, Hunt T, Alison MR, Cook HT, Wright NA, Poulsom R: Haematopoietic lineage-committed bone marrow cells, but not cloned cultured mesenchymal stem cells, contribute to regeneration of renal tubular epithelium after $\mathrm{HoCl} 2$-induced acute tubular injury. Cell Prolif 2008:41(4):575-91.

28. Fang TC, Alison MR, Cook HT, Jeffery R, Wright NA, Poulsom R: Proliferation of bone marrow-derived cells contributes to regeneration after folic acid-induced acute tubular injury. J Am Soc Nephrol 2005;16(6):1723-32.

29. Romani N, Clausen BE, Stoitzner P: Langerhans cells and more: langerin-expressing dendritic cell subsets in the skin. Immunol Rev 2010;234(1):120-41.

30. Modi BG, Neustadter J, Binda E, Lewis J, Filler RB, Roberts SJ, Kwong BY, Reddy S, Overton JD, Galan A, Tigelaar R, Cai L, Fu P, Shlomchik M, Kaplan DH, Hayday A,
Girardi M: Langerhans cells facilitate epithelial DNA damage and squamous cell carcinoma. Science 2012;335(6064):104-8.

31. Kaplan DH, Jenison MC, Saeland S, Shlomchik WD, Shlomchik MJ: Epidermal langerhans cell-deficient mice develop enhanced contact hypersensitivity. Immunity 2005;23(6):611-20

32. Rivollier A, Mazzorana M, Tebib J, Piperno M, Aitsiselmi T, Rabourdin-Combe C, Jurdic P, Servet-Delprat C: Immature dendritic cell transdifferentiation into osteoclasts: a novel pathway sustained by the rheumatoid arthritis microenvironment. Blood 2004;104(13):4029-37.

33. Schramm HM: The role of the osteoimmune axis in the inflammation of the inner auditory ear and with regard to the putative anticarcinogenetic principle: part 2 . Inflamm Allergy Drug Targets 2010;9(2):120-9.

34. Seluanov A, Hine C, Azpurua J, Feigenson M, Bozzella M, Mao Z, Catania KC, Gorbunova V: Hypersensitivity to contact inhibition provides a clue to cancer resistance of naked mole-rat. Proc Natl Acad Sci U S A 2009;106(46):19352-7.

35. Manov I, Hirsh M, Jancu TC, Malik A, Sotnichenko N, Band M, Avivi A, Shams I: Pronounced cancer resistance in a subterranean rodent, the blind mole-rat, Spalax: in vivo and in vitro evidence. BMC Biol 2013;11:91

36. Kischel P, Bellahcene A, Deux B, Lamour V, Dobson R, E DEP, Clezardin P, Castronovo V: Overexpression of CD9 in human breast cancer cells promotes the development of bone metastases. Anticancer Res 2012;32(12):5211-20.

37. Carloni V, Mazzocca A, Mello T, Galli A, Capaccioli S: Cell fusion promotes chemoresistance in metastatic colon carcinoma. Oncogene 2012;32(21):2649-60.

38. Buim ME, Lourenco SV, Carvalho KC, Cardim R, Pereira C, Carvalho AL, Fregnani $\mathrm{JH}$, Soares FA: Downregulation of CD9 protein expression is associated with aggressive behavior of oral squamous cell carcinoma. Oral Oncol 2010;46(3):166-71.

39. Okochi H, Kato M, Nashiro K, Yoshie O, Miyazono K, Furue M: Expression of tetra-spans transmembrane family (CD9, CD37, CD53, CD63, CD81 and CD82) in normal and neoplastic human keratinocytes: an association of $\mathrm{CD} 9$ with alpha 3 beta 1 integrin. Br J Dermatol 1997;137(6):856-63.

40. Guillemin GJ, Brew BJ: Microglia, macrophages, perivascular macrophages, and pericytes: a review of function and identification. J Leukoc Biol 2004;75(3):388-97.

41. Abdou AG: CD10 expression in tumour and stromal cells of bladder carcinoma: an association with bilharziasis. Apmis 2007;115(11):1206-18

42. Omran OM: CD10 and E-cad expression in urinary bladder urothelial and squamous cell carcinoma. J Environ Pathol Toxicol Oncol 2012;31(3):203-12.

43. Leccia F, Nardone A, Corvigno S, Vecchio LD, De Placido S, Salvatore F, Veneziani BM: Cytometric and biochemical characterization of human breast cancer cells reveals heterogeneous myoepithelial phenotypes. Cytometry A 2012;81(11):960-72.

44. Calvo F, Martin PM, Jabrane N, De Cremoux P, Magdelenat H: Human breast cancer cells share antigens with the myeloid monocyte lineage. Br J Cancer 1987;56(1):15-9.

45. Schmitt C, Voegelin M, Marin A, Schmitt M, Schegg F, Henon P, Guenot D, Tarnus C: Selective aminopeptidase-N (CD13) inhibitors with relevance to cancer chemotherapy. Bioorg Med Chem 2013;21(7):2135-44.

46. Lobba AR, Forni MF, Carreira AC, Sogayar MC: Differential expression of CD90 and CD14 stem cell markers in malignant breast cancer cell lines. Cytometry A 2012;81(12):1084-91.

47. Koh YW, Lee HJ, Ahn JH, Lee JW, Gong G: Expression of Lewis X is associated with poor prognosis in triple-negative breast cancer. Am J Clin Pathol 2013;139(6):746-53.

48. Athanasou NA, Quinn J: Immunophenotypic differences between osteoclasts and macrophage polykaryons: immunohistological distinction and implications for osteoclast ontogeny and function. J Clin Pathol 1990:43(12):997-1003.

49. Ghislin S, Obino D, Middendorp S, Boggetto N, Alcaide-Loridan C, Deshayes F: LFA-1 and ICAM-1 expression induced during melanoma-endothelial cell co-culture favors the transendothelial migration of melanoma cell lines in vitro. BMC Cancer 2012;12:455.

50. Yang SL, Tang YM, Shen HQ, Qian BQ, Song H, Shi SW, Ning BT, Chen YH, Xu WQ: [Expression of leucocyte cell-surface antigens on colon cancer cell line HR8348]. Zhejiang Da Xue Xue Bao Yi Xue Ban 2004;33(2):118-20.

51. Magnoni C, Giudice S, Pellacani G, Bertazzoni G, Longo C, Veratti E, Morini D, Benassi L, Vaschieri C, Azzoni P, De Pol A, Seidenari S, Tomasi A, Pollio A, Ponti G: Stem Cell Properties in Cell Cultures From Different Stage of Melanoma Progression. Appl Immunohistochem Mol Morphol 2013.

52. Buck K, Hug S, Seibold P, Ferschke I, Altevogt P, Sohn C, Schneeweiss A, Burwinkel B, Jager D, Flesch-Janys D, Chang-Claude J, Marme F: CD24 polymorphisms in breast cancer: impact on prognosis and risk. Breast Cancer Res Treat 2013;137(3):927-37.

53. Soave DF, Oliveira da Costa JP, da Silveira GG, Ianez RC, de Oliveira LR, Lourenco SV, Ribeiro-Silva A: CD44/CD24 immunophenotypes on clinicopathologic features of salivary glands malignant neoplasms. Diagn Pathol 2013;8:29.

54. Aigner S, Sthoeger ZM, Fogel M, Weber E, Zarn J, Ruppert M, Zeller Y, Vestweber D, Stahel R, Sammar M, Altevogt P: CD24, a mucin-type glycoprotein, is a ligand for P-selectin on human tumor cells. Blood 1997:89(9):3385-95.

55. Caly Dde N, Viana A, Rapoport A, Dedivitis RA, Curioni OA, Cernea CR, Brandao LG: Indications and pitfalls of immunohistochemistry in head and neck cancer. Braz J Otorhinolaryngol 2013;79(1):75-81

56. Woodhead VE, Binks MH, Chain BM, Katz DR: From sentinel to messenger: an extended phenotypic analysis of the monocyte to dendritic cell transition. Immunology 1998:94(4):552-9.

57. Tang DG, Chen YQ, Newman PJ, Shi L, Gao X, Diglio CA, Honn KV: Identification of PECAM-1 in solid tumor cells and its potential involvement in tumor cell adhesion to endothelium. J Biol Chem 1993;268(30):22883-94.

58. Uray IP, Liang Y, Hyder SM: Estradiol down-regulates CD36 expression in human breast cancer cells. Cancer Lett 2004:207(1):101-7.

59. Vallbo C, Wang W, Damber JE: The expression of thrombospondin-1 in benign prostatic hyperplasia and prostatic intraepithelial neoplasia is decreased in prostate cancer. BJU Int 2004;93(9):1339-43.

60. Chen M, Pych E, Corpron C, Harmon CM: Regulation of CD36 expression in human melanoma cells. Adv Exp Med Biol 2002:507:337-42.

61. Karimi-Busheri F, Zadorozhny V, Li T, Lin H, Shawler DL, Fakhrai H: Pivotal role of CD38 biomarker in combination with CD24, EpCAM, and ALDH for identification of H460 derived lung cancer stem cells. J Stem Cells 2011;6(1):9-20. 
62. Perenkov AD, Novikov DV, Sakharnov NA, Aliasova AV, Utkin OV, Baryshnikov A, Novikov VV: [Heterogeneous expression of CD38 gene in tumor tissue in patients with colorectal cancer]. Mol Biol (Mosk) 2012;46(5):786-91.

63. Yamaguchi H, Tanaka F, Sadanaga N, Ohta M, Inoue H, Mori M: Stimulation of CD40 inhibits Fas- or chemotherapy-mediated apoptosis and increases cell motility in human gastric carcinoma cells. Int J Oncol 2003;23(6):1697-702.

64. Elmetwali T, Searle PF, McNeish I, Young LS, Palmer DH: CD40 ligand induced cytotoxicity in carcinoma cells is enhanced by inhibition of metalloproteinase cleavage and delivery via a conditionally-replicating adenovirus. Mol Cancer 2010;9:52.

65. Merono A, Lucena C, Lopez A, Garrido JJ, Perez de LL, Llanes D: Immunohistochemical analysis of beta3 integrin (CD61): expression in pig tissues and human tumors. Histol Histopathol 2002;17(2):347-52.

66. Anderson KM, Guinan P, Rubenstein M: The effect of normoxia and hypoxia on a prostate (PC-3) CD44/CD41 cell side fraction. Anticancer Res 2011;31(2):487-94

67. Gekas C, Graf T: CD41 expression marks myeloid-biased adult hematopoietic stem cells and increases with age. Blood 2013;121(22):4463-72.

68. Balikova A, Jaager K, Viil J, Maimets T, Kadaja-Saarepuu L: Leukocyte marker CD43 promotes cell growth in co-operation with beta-catenin in non-hematopoietic cancer cells. Int J Oncol 2012;41(1):299-309.

69. Goodison S, Urquidi V, Tarin D: CD44 cell adhesion molecules. Mol Pathol 1999:52(4):189-96.

70. Melotti A, Daga A, Marubbi D, Zunino A, Mutti L, Corte G: In vitro and in vivo characterization of highly purified human mesothelioma derived cells. BMC Cancer 2010;10:54

71. Nuutila J, Jalava-Karvinen P, Hohenthal U, Kotilainen P, Pelliniemi TT, Nikoskelainen J, Lilius EM: Use of complement regulators, CD35, CD46, CD55, and CD59, on leukocytes as markers for diagnosis of viral and bacterial infections. Hum Immunol 2013;74(5):522-30.

72. Lee G, Zhu M, Ge B, Potzold S: Widespread expressions of immunoglobulin superfamily proteins in cancer cells. Cancer Immunol Immunother 2011;61(1):89-99.

73. Han X, Sterling $\mathrm{H}$, Chen $\mathrm{Y}$, Saginario C, Brown EJ, Frazier WA, Lindberg FP, Vignery $\mathrm{A}: \mathrm{CD} 47$, a ligand for the macrophage fusion receptor, participates in macrophage multinucleation. J Biol Chem 2000;275(48):37984-92.

74. Jockers JJ, Novak N: Different expression of adhesion molecules and tetraspanins of monocytes of patients with atopic eczema. Allergy 2006;61(12):1419-22.

75. Clezardin P, Frappart L, Clerget M, Pechoux C, Delmas PD: Expression of thrombospondin (TSP1) and its receptors (CD36 and CD51) in normal, hyperplastic, and neoplastic human breast. Cancer Res 1993;53(6):1421-30

76. $\mathrm{Hu} \mathrm{Y,} \mathrm{Wu} \mathrm{G,} \mathrm{Rusch} \mathrm{M,} \mathrm{Lukes} \mathrm{L,} \mathrm{Buetow} \mathrm{KH,} \mathrm{Zhang} \mathrm{J,} \mathrm{Hunter} \mathrm{KW:} \mathrm{Integrated}$ cross-species transcriptional network analysis of metastatic susceptibility. Proc Natl Acad Sci U S A 2012;109(8):3184-9.

77. Ferreira-Facio CS, Milito C, Botafogo V, Fontana M, Thiago LS, Oliveira E, da Rocha-Filho AS, Werneck F, Forny DN, Dekermacher S, de Azambuja AP, Ferman SE, de Faria PA, Land MG, Orfao A, Costa ES: Contribution of multiparameter flow cytometry immunophenotyping to the diagnostic screening and classification of pediatric cancer. PLoS One 2013;8(3):e55534.

78. Anguille S, Lion E, Tel J, de Vries IJ, Coudere K, Fromm PD, Van Tendeloo VF, Smits EL, Berneman ZN: Interleukin-15-induced CD56(+) myeloid dendritic cells combine potent tumor antigen presentation with direct tumoricidal potential. PLoS One 2012;7(12):e51851

79. Fishelson Z, Donin N, Zell S, Schultz S, Kirschfink M: Obstacles to cancer immunotherapy: expression of membrane complement regulatory proteins (mCRPs) in tumors. Mol Immunol 2003:40(2-4):109-23.

80. Husheem M, Nyman JK, Vaaraniemi J, Vaananen HK, Hentunen TA: Characterization of circulating human osteoclast progenitors: development of in vitro resorption assay. Calcif Tissue Int 2005;76(3):222-30.

81. Lindeman GJ, Visvader JE: Insights into the cell of origin in breast cancer and breast cancer stem cells. Asia Pac J Clin Oncol 2010;6(2):89-97.

82. Kim DH, Kwon MS: Role of fine needle aspiration cytology, cell block preparation and CD63, P63 and CD56 immunostaining in classifying the specific tumor type of the lung. Acta Cytol 2010;54(1):55-9.

83. Gottfried E, Kunz-Schughart LA, Weber A, Rehli M, Peuker A, Muller A, Kastenberger M, Brockhoff G, Andreesen R, Kreutz M: Expression of CD68 in non-myeloid cell types. Scand J Immunol 2008;67(5):453-63.

84. Doussis IA, Gatter KC, Mason DY: CD68 reactivity of non-macrophage derived tumours in cytological specimens. J Clin Pathol 1993;46(4):334-6.

85. Xiao Y, Song JY, de Vries TJ, Fatmawati C, Parreira DB, Langenbach GE, Babala N, Nolte MA, Everts $\mathrm{V}$, Borst J: Osteoclast precursors in murine bone marrow express CD27 and are impeded in osteoclast development by CD70 on activated immune cells. Proc Natl Acad Sci U S A 2013;110(30):12385-90.

86. Law CL, McEarchern JA, Grewal IS: Novel antibody-based therapeutic agents targeting CD70: a potential approach for treating Waldenstrom's macroglobulinemia. Clin Lymphoma Myeloma 2009:9(1):90-3.

87. Rust S, Guillard S, Sachsenmeier K, Hay C, Davidson M, Karlsson A, Karlsson R, Brand E, Lowne D, Elvin J, Flynn M, Kurosawa G, Hollingsworth R, Jermutus L, Minter R: Combining phenotypic and proteomic approaches to identify membrane targets in a 'triple negative' breast cancer cell type. Mol Cancer 2013;12:11.

88. Shechter R, Miller O, Yovel G, Rosenzweig N, London A, Ruckh J, Kim KW, Klein E, Kalchenko V, Bendel P, Lira SA, Jung S, Schwartz M: Recruitment of beneficial M2 macrophages to injured spinal cord is orchestrated by remote brain choroid plexus. Immunity 2013;38(3):555-69.

89. Loi S, Pommey S, Haibe-Kains B, Beavis PA, Darcy PK, Smyth MJ, Stagg J: CD73 promotes anthracycline resistance and poor prognosis in triple negative breast cancer. Proc Natl Acad Sci U S A 2013;110(27):11091-6.

90. Takahashi M, Takahashi M, Shinohara F, Takada H, Rikiishi H: Effects of superantigen and lipopolysaccharide on induction of CD80 through apoptosis of human monocytes. Infect Immun 2001;69(6):3652-7.

91. Chen C, Qu OX, Shen Y, Mu CY, Zhu YB, Zhang XG, Huang JA: Induced expression of B7-H4 on the surface of lung cancer cell by the tumor-associated macrophages: a potential mechanism of immune escape. Cancer Lett 2012;317(1):99-105.
92. Iwai K, Ishii M, Ohshima S, Miyatake K, Saeki Y: Expression and function of transmembrane-4 superfamily (tetraspanin) proteins in osteoclasts: reciprocal roles of Tspan-5 and NET-6 during osteoclastogenesis. Allergol Int 2007;56(4):457-63.

93. Loser K, Scherer A, Krummen MB, Varga G, Higuchi T, Schwarz T, Sharpe AH, Grabbe S, Bluestone JA, Beissert S: An important role of CD80/CD86-CTLA-4 signaling during photocarcinogenesis in mice. J Immunol 2005;174(9):5298-305.

94. Hildenbrand R, Schaaf A, Dorn-Beineke A, Allgayer H, Sutterlin M, Marx A, Stroebel $\mathrm{P}$ : Tumor stroma is the predominant uPA-, UPAR-, PAI-1-expressing tissue in human breast cancer: prognostic impact. Histol Histopathol 2009;24(7):869-77.

95. Eastman BM, Jo M, Webb DL, Takimoto S, Gonias SL: A transformation in the mechanism by which the urokinase receptor signals provides a selection advantage for estrogen receptor-expressing breast cancer cells in the absence of estrogen. Cell Signal 2012;24(9):1847-55

96. Metzger W, Schimmelpfennig L, Schwab B, Sossong D, Dorst N, Bubel M, Gorg A, Putz N, Wennemuth G, Pohlemann T, Oberringer M: Expansion and differentiation of human primary osteoblasts in two- and three-dimensional culture. Biotech Histochem 2012;88(2):86-102.

97. Feller N, Kelder A, Westra G, Ossenkoppele GJ, Schuurhuis GJ: Positive selection for CD90 as a purging option in acute myeloid leukemia stem cell transplants. Cytometry B Clin Cytom 2008;74(1):9-16.

98. Dabrowski A, Osada J, Dabrowska MI, Wereszczynska-Siemiatkowska U: Monocyte subsets and natural killer cells in acute pancreatitis. Pancreatology 2008;8(2):126-34.

99. Abbott RJ, Spendlove I, Roversi P, Fitzgibbon H, Knott V, Teriete P, McDonnell JM, Handford PA, Lea SM: Structural and functional characterization of a novel T cell receptor co-regulatory protein complex, CD97-CD55. J Biol Chem 2007;282(30):22023-32

100. Mori K, Nishimura $M$, Tsurudome $M$, Ito M, Nishio M, Kawano M, Kozuka $Y$, Yamashita Y, Komada H, Uchida A, Ito Y: The functional interaction between CD98 and CD147 in regulation of virus-induced cell fusion and osteoclast formation. Med Microbiol Immunol 2004;193(4):155-62.

101. Kaira K, Oriuchi N, Imai H, Shimizu $K$, Yanagitani N, Sunaga N, Hisada T, Kawashima $O$, Kamide $Y$, Ishizuka T, Kanai $Y$, Nakajima T, Mori M: CD98 expression is associated with poor prognosis in resected non-small-cell lung cancer with lymph node metastases. Ann Surg Oncol 2009;16(12):3473-81.

102. Ziebarth AJ, Nowsheen S, Steg AD, Shah MM, Katre AA, Dobbin ZC, Han HD, Lopez-Berestein G, Sood AK, Conner M, Yang ES, Landen CN: Endoglin (CD105) contributes to platinum resistance and is a target for tumor-specific therapy in epithelial ovarian cancer. Clin Cancer Res 2013;19(1):170-82.

103. Yu HK, Lee HJ, Choi HN, Ahn JH, Choi JY, Song HS, Lee KH, Yoon Y, Yi LS, Kim JS, Kim SJ, Kim TJ: Characterization of CD45-/CD31+/CD105+ Circulating Cells in the Peripheral Blood of Patients with Gynecologic Malignancies. Clin Cancer Res 2013.

104. Lin KY, Lu D, Hung CF, Peng S, Huang L, Jie C, Murillo F, Rowley J, Tsai YC, He L, Kim DJ, Jaffee E, Pardoll D, Wu TC: Ectopic expression of vascular cell adhesion molecule-1 as a new mechanism for tumor immune evasion. Cancer Res 2007;67(4):1832-41.

105. Oshima T, Sato S, Kato J, Ito Y, Watanabe T, Tsuji I, Hori A, Kurokawa T, Kokubo T: Nectin- 2 is a potential target for antibody therapy of breast and ovarian cancers. Mol Cancer 2013;12:60.

106. Miao X, Yang ZL, Xiong L, Zou Q, Yuan Y, Li J, Liang L, Chen M, Chen S: Nectin-2 and DDX3 are biomarkers for metastasis and poor prognosis of squamous cell/adenosquamous carcinomas and adenocarcinoma of gallbladder. Int J Clin Exp Pathol 2013;6(2):179-90.

107. Pende D, Castriconi R, Romagnani P, Spaggiari GM, Marcenaro S, Dondero A, Lazzeri E, Lasagni L, Martini S, Rivera P, Capobianco A, Moretta L, Moretta A, Bottino C: Expression of the DNAM-1 ligands, Nectin-2 (CD112) and poliovirus receptor (CD155), on dendritic cells: relevance for natural killer-dendritic cell interaction. Blood 2006;107(5):2030-6.

108. Ide H, Seligson DB, Memarzadeh S, Xin L, Horvath S, Dubey P, Flick MB, Kacinski $\mathrm{BM}$, Palotie A, Witte ON: Expression of colony-stimulating factor 1 receptor during prostate development and prostate cancer progression. Proc Natl Acad Sci U S A 2002;99(22):14404-9.

109. Morandi A, Barbetti V, Riverso M, Dello Sbarba P, Rovida E: The colony-stimulating factor-1 (CSF-1) receptor sustains ERK1/2 activation and proliferation in breast cancer cell lines. PLoS One 2011;6(11):e27450.

110. Sinha N, Mukhopadhyay S, Das DN, Panda PK, Bhutia SK: Relevance of cancer initiating/stem cells in carcinogenesis and therapy resistance in oral cancer. Oral Oncol 2013;49(9):854-62.

111. Gattei V, Aldinucci D, Quinn JM, Degan M, Cozzi M, Perin V, Iuliis AD, Juzbasic S, Improta S, Athanasou NA, Ashman LK, Pinto A: Human osteoclasts and preosteoclast cells (FLG 29.1) express functional c-kit receptors and interact with osteoblast and stromal cells via membrane-bound stem cell factor. Cell Growth Differ 1996;7(6):753-63.

112. Predina J, Eruslanov E, Judy B, Kapoor V, Cheng G, Wang LC, Sun J, Moon EK, Fridlender ZG, Albelda S, Singhal S: Changes in the local tumor microenvironment in recurrent cancers may explain the failure of vaccines after surgery. Proc Natl Acad Sci U S A 2013;110(5):E415-24

113. Puri S, Puri S, Mahapatra AK, Hussain E, Sarkar C, Sinha S, Joshi BH: A review of studies on targeting interleukin 4 receptor for central nervous system malignancy. Curr Mol Med 2009:9(6):732-9.

114. Bertolini G, Roz L, Perego P, Tortoreto M, Fontanella E, Gatti L, Pratesi G, Fabbri A, Andriani F, Tinelli S, Roz E, Caserini R, Lo Vullo S, Camerini T, Mariani L, Delia D, Calabro E, Pastorino U, Sozzi G: Highly tumorigenic lung cancer CD133+ cells display stem-like features and are spared by cisplatin treatment. Proc Natl Acad Sci U S A 2009;106(38):16281-6.

115. Chan KS, Espinosa I, Chao M, Wong D, Ailles L, Diehn M, Gill H, Presti J, Jr., Chang HY, van de Rijn M, Shortliffe L, Weissman IL: Identification, molecular characterization, clinical prognosis, and therapeutic targeting of human bladder tumor-initiating cells. Proc Natl Acad Sci U S A 2009;106(33):14016-21.

116. Bonetti MI, Pieri L, Domenici L, Urbani S, Romano G, Aldinucci A, Ballerini C, Monici M, Saccardi R, Basile V, Bosi A, Romagnoli P: Dendritic cells with lymphocyte-stimulating activity differentiate from human CD133 positive precursors. Blood 2011;117(15):3983-95. 
117. Bellarosa D, Bressan A, Bigioni M, Parlani M, Maggi CA, Binaschi M: SAHA/Vorinostat induces the expression of the CD137 receptor/ligand system and enhances apoptosis mediated by soluble CD137 receptor in a human breast cancer cell line. Int J Oncol 2012;41(4):1486-94.

118. Tang Q, Jiang D, Shao Z, Martinez Gomez JM, Schwarz H: Species difference of CD137 ligand signaling in human and murine monocytes. PLoS One 2011;6(1):e16129.

119. Wang Z, Yan X: CD146, a multi-functional molecule beyond adhesion. Cancer Lett 2013;330(2):150-62.

120. Goodale D, Phay C, Brown W, Gray-Statchuk L, Furlong P, Lock M, Chin-Yee I, Keeney M, Allan AL: Flow cytometric assessment of monocyte activation markers and circulating endothelial cells in patients with localized or metastatic breast cancer. Cytometry B Clin Cytom 2009;76(2):107-17.

121. Zhang H, Zhang J, Wang Z, Lu D, Feng J, Yang D, Chen X, Yan X: CD146 is a potential marker for the diagnosis of malignancy in cervical and endometrial cancer. Oncol Lett 2013:5(4):1189-1194.

122. Imbert AM, Garulli C, Choquet E, Koubi M, Aurrand-Lions M, Chabannon C: CD146 expression in human breast cancer cell lines induces phenotypic and functional changes observed in Epithelial to Mesenchymal Transition. PLoS One 2012;7(8):e43752.

123. Pinheiro C, Reis RM, Ricardo S, Longatto-Filho A, Schmitt F, Baltazar F: Expression of monocarboxylate transporters 1,2, and 4 in human tumours and their association with CD147 and CD44. J Biomed Biotechnol 2010;2010:427694.

124. Casado JG, Pawelec G, Morgado S, Sanchez-Correa B, Delgado E, Gayoso I, Duran E, Solana R, Tarazona R: Expression of adhesion molecules and ligands for activating and costimulatory receptors involved in cell-mediated cytotoxicity in a large panel of human melanoma cell lines. Cancer Immunol Immunother 2009;58(9):1517-26.

125. Avila-Moreno F, Lopez-Gonzalez JS, Galindo-Rodriguez G, Prado-Garcia H, Bajana S, Sanchez-Torres C: Lung squamous cell carcinoma and adenocarcinoma cell lines use different mediators to induce comparable phenotypic and functional changes in human monocyte-derived dendritic cells. Cancer Immunol Immunother 2006;55(5):598-611.

126. Tang J, Zhang L, She X, Zhou G, Yu F, Xiang J, Li G: Inhibiting CD164 expression in colon cancer cell line HCT116 leads to reduced cancer cell proliferation, mobility, and metastasis in vitro and in vivo. Cancer Invest 2012;30(5):380-9.

127. Watt SM, Buhring HJ, Rappold I, Chan JY, Lee-Prudhoe J, Jones T, Zannettino AC, Simmons PJ, Doyonnas R, Sheer D, Butler LH: CD164, a novel sialomucin on $\mathrm{CD} 34(+)$ and erythroid subsets, is located on human chromosome 6q21. Blood 1998;92(3):849-66.

128. Ofori-Acquah SF, King JA: Activated leukocyte cell adhesion molecule: a new paradox in cancer. Transl Res 2008;151(3):122-8.

129. Levesque MC, Heinly CS, Whichard LP, Patel DD: Cytokine-regulated expression of activated leukocyte cell adhesion molecule (CD166) on monocyte-lineage cells and in rheumatoid arthritis synovium. Arthritis Rheum 1998;41(12):2221-9.

130. Schafer H, Dieckmann C, Korniienko O, Moldenhauer G, Kiefel H, Salnikov A, Kruger A, Altevogt P, Sebens S: Combined treatment of L1CAM antibodies and cytostatic drugs improve the therapeutic response of pancreatic and ovarian carcinoma. Cancer Lett 2012;319(1):66-82.

131. Xing Q, de Vos P, Faas MM, Ye Q, Ren Y: LPS promotes pre-osteoclast activity by up-regulating CXCR4 via TLR-4. J Dent Res 2011;90(2):157-62.

132. Gorczynski RM, Chen Z, Diao J, Khatri I, Wong K, Yu K, Behnke J: Breast cancer cell CD200 expression regulates immune response to EMT6 tumor cells in mice. Breast Cancer Res Treat 2010;123(2):405-15.

133. Leroy X, Buisine MP, Leteurtre E, Aubert S, Buob D, Porchet N, Copin MC: [MUC1 (EMA): A key molecule of carcinogenesis?]. Ann Pathol 2006;26(4):257-66.

134. Huang G, Wen Q, Zhao Y, Gao Q, Bai Y: NF-kappaB plays a key role in inducing CD274 expression in human monocytes after lipopolysaccharide treatment. PLoS One 2013;8(4):e61602.

135. Sznol M, Chen L: Antagonist Antibodies to PD-1 and B7-H1 (PD-L1) in the Treatment of Advanced Human Cancer--Response. Clin Cancer Res 2013.

136. Trzpis M, McLaughlin PM, de Leij LM, Harmsen MC: Epithelial cell adhesion molecule: more than a carcinoma marker and adhesion molecule. Am J Pathol 2007;171(2):386-95.

137. Zenger S, Ek-Rylander B, Andersson G: Biogenesis of tartrate-resistant acid phosphatase isoforms $5 \mathrm{a}$ and $5 \mathrm{~b}$ in stably transfected MDA-MB-231 breast cancer epithelial cells. Biochim Biophys Acta 2010;1803(5):598-607.

138. Honig A, Rieger L, Kapp M, Krockenberger M, Eck M, Dietl J, Kammerer U: Increased tartrate-resistant acid phosphatase (TRAP) expression in malignant breast, ovarian and melanoma tissue: an investigational study. BMC Cancer 2006;6:199.

139. Santini D PG, Roato I, Godio L, Pantano F, Grasso D, Russo A, Vincenzi B, Fratto ME, Sabbatini R, Della Pepa C, Porta C, Del Conte A, Schiavon G, Berruti A, Tomasino RM, Papotti M, Papapietro N, Onetti Muda A, Denaro V, Tonini G: Expression pattern of receptor activator of NFKB (RANK) in a series of primary solid tumors and related bone metastases. J Cell Physiol 2010;226(3):780-4.

140. Littlewood-Evans AJ, Bilbe G, Bowler WB, Farley D, Wlodarski B, Kokubo T, Inaoka T, Sloane J, Evans DB, Gallagher JA: The osteoclast-associated protease cathepsin K is expressed in human breast carcinoma. Cancer Res 1997;57(23):5386-90.

141. Takayanagi $\mathrm{H}$ : Mechanistic insight into osteoclast differentiation in osteoimmunology. J Mol Med (Berl) 2005;83(3):170-9.

142. Shabo I, Olsson H, Stal O, Svanvik J: Breast Cancer Expression of DAP12 is Associated With Skeletal and Liver Metastases and Poor Survival. Clin Breast Cancer 2013;13(5):371-7.

143. Wang D, Huang P, Zhu B, Sun L, Huang Q, Wang J: Induction of estrogen receptor alpha-36 expression by bone morphogenetic protein 2 in breast cancer cell lines. Mol Med Rep 2012;6(3):591-6.

144. Oksala N, Levula M, Pelto-Huikko M, Kytomaki L, Soini JT, Salenius J, Kahonen M, Karhunen PJ, Laaksonen R, Parkkila S, Lehtimaki T: Carbonic anhydrases II and XII are up-regulated in osteoclast-like cells in advanced human atherosclerotic plaques-Tampere Vascular Study. Ann Med 2010;42(5):360-70.

145. Monego G, Lauriola L, Ramella S, D'Angelillo RM, Lanza P, Granone P, Ranelletti FO: Parathyroid hormone-related peptide and parathyroid hormone-related peptide receptor type 1 expression in human lung adenocarcinoma. Chest 2010;137(4):898-908

146. Nakashima M, Nakayama T, Ohtsuru A, Fukada E, Niino D, Yamazumi K, Naito S, Ito M, Sekine I: Expression of parathyroid hormone (PTH)-related peptide (PthrP) and PTH/PTHrP receptor in osteoclast-like giant cells. Pathol Res Pract 2003;199(2):85-92

147. Massfelder T, Lang H, Schordan E, Lindner V, Rothhut S, Welsch S, Simon-Assmann $\mathrm{P}$, Barthelmebs M, Jacqmin D, Helwig JJ: Parathyroid hormone-related protein is an essential growth factor for human clear cell renal carcinoma and a target for the von Hippel-Lindau tumor suppressor gene. Cancer Res 2004;64(1):180-8.

148. Lupp A, Klenk C, Rocken C, Evert M, Mawrin C, Schulz S: Immunohistochemical identification of the PTHR1 parathyroid hormone receptor in normal and neoplastic human tissues. Eur J Endocrinol 2010;162(5):979-86.

149. Sato Y, Goto Y, Narita N, Hoon DS: Cancer Cells Expressing Toll-like Receptors and the Tumor Microenvironment. Cancer Microenviron 2009;2 Suppl 1:205-14.

150. Rao VH, Kandel A, Lynch D, Pena Z, Marwaha N, Deng C, Watson P, Hansen LA: A positive feedback loop between HER2 and ADAM12 in human head and neck cancer cells increases migration and invasion. Oncogene 2011;31(23):2888-98.

151. Frohlich C, Nehammer C, Albrechtsen R, Kronqvist P, Kveiborg M, Sehara-Fujisawa A, Mercurio AM, Wewer UM: ADAM12 produced by tumor cells rather than stromal cells accelerates breast tumor progression. Mol Cancer Res 2011;9(11):1449-61.

152. Yagi M, Miyamoto T, Toyama Y, Suda T: Role of DC-STAMP in cellular fusion of osteoclasts and macrophage giant cells. J Bone Miner Metab 2006;24(5):355-8.

153. Engin F, Lee B: NOTCHing the bone: insights into multi-functionality. Bone 2010;46(2):274-80

154. Guo S, Liu M, Gonzalez-Perez RR: Role of Notch and its oncogenic signaling crosstalk in breast cancer. Biochim Biophys Acta 2011;1815(2):197-213. 